\title{
2.4.5. Ocenianie kształtujące - ocenianie wspierające uczniów ze specjalnymi potrzebami edukacyjnymi
}

DOI: 10.47050/65591838.228-234

Urszula Skrzypczak

Podejście do oceniania kształtującego (OK) zmienia się i ewoluuje w ostatnich latach. Nauczyciele uczą się korzystać z tej strategii - poznają ją, stosują i wymieniają się doświadczeniami, by pełniej wspierać wszystkich uczniów, w tym tych ze specjalnymi potrzebami edukacyjnymi.

Zmieniła się również definicja oceniania kształtującego, które - według Danuty Sterny (2016) - „polega na pozyskiwaniu przez nauczyciela i ucznia w trakcie nauczania informacji, które pozwolą rozpoznać, jak przebiega proces uczenia się, aby:

$\rightarrow$ nauczyciel modyfikował dalsze nauczanie,

$\rightarrow$ uczeń otrzymywał informację zwrotną pomagającą mu się uczyć".

Komitet Psychologii PAN odejście od stopni na rzecz oceny kształtującej w ocenianiu bieżącym uzasadnił następująco: „Ocena ze strony nauczyciela odgrywa swoją formatywną rolę, czyli jest prorozwojowa, tylko wtedy, gdy dostarcza dziecku informacji pomagających mu się uczyć, a więc umożliwia: (1) uświadomienie sobie, co robi dobrze, a co źle, (2) zrozumienie istoty popełnianych błędów, (3) wskazuje drogi poprawy, ale przede wszystkim, (4) wskazuje, w czym dziecko jest kompetentne, co osiągnęło dzięki swemu wysiłkowi. Taki sposób oceniania wzmacnia wytrwałość uczącego się dziecka, buduje jego poczucie sprawstwa, w tym odpowiedzialności za własne działania, a w efekcie kształtuje zdolność samoregulacji, tak ważną w kolejnych etapach kształcenia oraz w życiu. 
Ocena według stopni, szczególnie gdy jest jedyną albo najczęstszą formą oceniania, nie niesie za sobą prorozwojowej informacji zwrotnej dla dziecka, w głównej mierze służy porównywaniu dzieci ze sobą. We wczesnym etapie edukacji, kiedy dzieci dopiero opanowują różne strategie uczenia się, nie pomaga im w tym procesie, a w przypadku dzieci natrafiających na różnorodne trudności w uczeniu się może hamować ich motywację i być wręcz źródłem ich bezradności.

Ocenianie opisowe może początkowo być uciążliwe dla nauczyciela, ale niesie ze sobą cenne dla niego informacje. Pomaga mu w dobieraniu trafnych i potrzebnych dla dzieci metod wspomagania ich rozwoju, szczególnie w zakresie strategii uczenia się, metod pomocy w sytuacjach, gdy dzieci mają trudności w uczeniu się, a także metod rozwijania ich specjalnych zdolności i talentów"1.

Strategie oceniania kształtującego można wykorzystać w procesie uczenia się i nauczania uczniów ze specjalnymi potrzebami edukacyjnymi na kilka sposobów.

\section{Strategia I: Określanie i wyjaśnianie uczniom celów uczenia się i kryteriów sukcesu (Sterna 2014)}

Określenie celu to podstawowe działanie rozpoczynające proces uczenia się. Uświadamia ono nauczycielowi, a także uczniowi, po co podejmowany jest wysiłek związany ze zdobyciem konkretnej wiedzy i umiejętności, do czego te elementy przydadzą się w dalszej edukacji, w życiu codziennym lub w praktyce. Już na tym etapie ważne jest, by nauczyciel wspomagający wiedział, czy cel lekcji dla uczniów ze specjalnymi potrzebami edukacyjnymi będzie taki sam, jak dla innych, czy też nastąpi modyfikacja w tym zakresie. Warto zadać sobie proste pytanie: „Dlaczego tego nauczam?". Uczniowie lepiej przyswajają wiedzę, jeżeli wiedzą, po co to robią. Doświadczeni pedagodzy podejmują działania związane z określaniem celów lekcji (w języku zrozumiałym dla uczniów), są też gotowi do negocjacji w tym zakresie. Dobrze sformułowany cel rozpoczyna uczenie się, a końcowe sprawdzenie stanu jego realizacji „,zamyka” proces edukacyjny w odniesieniu do lekcji, działu czy podstawy programowej. Przeprowadzenie podsumowania 
jest niezwykle istotne, ponieważ dostarcza nauczycielowi bezcennych informacji.

Określanie kryteriów sukcesu i wyjaśnianie ich uczniom porządkuje proces uczenia się. "NaCoBeZU" („Na co będziemy zwracać uwagę") to warunki, które precyzują, jaką wiedzę uczeń ma zdobyć. Jest tutaj miejsce na wprowadzanie przez nauczyciela modyfikacji (zarówno jakościowych, jak i ilościowych), w związku ze specjalnymi potrzebami edukacyjnymi konkretnych podopiecznych. Trzeba pamiętać o wprowadzanych zmianach i koniecznie uwzględniać je, przygotowując kryteria sukcesu dla uczniów z różnymi deficytami, np. w sprawdzianie podsumowującym dany dział czy w pracy domowej. Podobnie jak cele, powinny być one czytelne dla uczniów - umożliwiają bowiem monitorowanie procesu edukacyjnego, dokonanie samooceny przez każde dziecko, planowanie dalszych działań, następnych lekcji. Uczniowie młodsi i ze specjalnymi potrzebami edukacyjnymi często korzystają $\mathrm{z}$ "nacobezowników" zawierających stałe kryteria sukcesu, np. dotyczące zasad pisania konkretnych form wypowiedzi, czytania, rozwiązywania zadań tekstowych, wykonywania prac technicznych, plastycznych. Kryteria powinny być określane do każdej pracy wykonywanej przez uczniów. Ambitnym wyzwaniem jest ustalanie ich z uczniami i negocjowanie z nimi kwestii ilościowych.

\section{Strategia II: Organizowanie w klasie dyskusji, zadawanie pytań i realizowanie zadań dających informacje, czy i jak uczniowie się uczą (Sterna 2014)}

Stosowanie tej strategii ma szczególne znaczenie w pracy z uczniami ze specjalnymi potrzebami edukacyjnymi. Zakłada ona ciągły dialog nauczyciela z podopiecznymi, dotyczący tego, co już zrozumieli i czemu należy poświęcić więcej czasu. Wiąże się ze stałym monitorowaniem procesu uczenia się, a także z poznaniem i określeniem „strefy najbliższego rozwoju" ucznia. W dialogu następuje rozpoznanie jego indywidualnych możliwości i dostosowanie odpowiednich do nich zadań, poleceń oraz kolejnych działań edukacyjnych. Niezbędne są tu umiejętności zadawania pytań i uważnego, aktywnego słuchania. Strategia zakłada aktywność zarówno po stronie nauczyciela, jak i ucznia. Opiera się na budowaniu relacji związanych z poczuciem bezpieczeństwa i stwarzaniu warunków nieskrępowanego wyrażania swoich odczuć i opinii. 
W ocenianiu kształtującym ważne są podstawowe zalecenia związane z:

$\rightarrow$ oczekiwaniem na odpowiedź (co najmniej pięć sekund),

$\rightarrow$ poprzedzaniem odpowiedzi na postawione pytania rozmową w bezpiecznych parach,

$\rightarrow$ stosowaniem zasady niepodnoszenia rąk lub losowania patyczków,

$\rightarrow$ prawem do błędów i wykorzystywaniem ich w procesie uczenia się,

$\rightarrow$ wykorzystaniem pytań otwartych.

Dzięki tej strategii nauczyciel w dowolnym momencie lekcji wie, na jakim etapie procesu edukacyjnego znajduje się uczeń, a w związku z tym może dostosować przekazywanie wiedzy do potrzeb ucznia (określonych na podstawie informacji uzyskanych w trakcie rozmowy) oraz stosować pytania i techniki pomagające w nauce.

\section{Strategia III: Udzielanie uczniom informacji zwrotnych, które umożliwiają im czynienie postępów (Sterna 2014)}

Informacja zwrotna wiąże się bezpośrednio z ustalonymi wcześniej i znanymi uczniowi kryteriami sukcesu. Pełna składa się z czterech elementów i jest kluczowa w procesie uczenia się:

1. Co uczeń zrobił dobrze?

Docenienie prawidłowo wykonanej pracy jest podstawą budowania motywacji do dalszego uczenia się. Daje uczniowi poczucie sprawstwa, umożliwia doskonalenie samokontroli oraz realizacji zadań zgodnie z wymaganymi procedurami. To po tym etapie każda osoba, a szczególnie ze specjalnymi potrzebami edukacyjnymi, jest gotowa przyjąć odpowiedzi na drugie i trzecie pytanie postawione w informacji zwrotnej.

2. Co należy poprawić?

3. Jak należy poprawić?

Wskazanie obszarów, które należy zmienić, nie wypełnia wymagań dobrej informacji zwrotnej. Niezbędna do dalszego rozwoju jest wskazówka, a czasami szczegółowa procedura, dotycząca sposobu poprawienia błędu. Procedura może być wsparciem dla ucznia, który potrzebuje dodatkowych informacji i precyzyjnych poleceń. Może ona pełnić funkcję pomocniczą wobec kryteriów, precyzyjnie ukierunkowując działania ucznia, być drogowskazem do sukcesu, nie zawężając wcześniej ustalonych kryteriów. Wskazując obszary do poprawy, 
nie należy wychodzić poza wcześniej ustalone warunki sukcesu, dostosowane do możliwości ucznia ze specjalnymi potrzebami edukacyjnymi.

W tej części opisu ważna jest umiejętność nauczyciela związana z udzielaniem informacji zwrotnej w języku faktów. Opisową wiadomość dla ucznia, który popełnia dużo błędów i ma problemy z realizacją ustalonego "NaCoBeZU", można zakończyć na trzecim elemencie.

Kolejny jest bardzo ważny dla osób, które przejawiają kierunkowe zdolności, pasje w jakiejś dziedzinie, uzdolnienia, ponadprzeciętne zainteresowanie danym przedmiotem. Udzielenie odpowiedzi na postawione poniżej pytanie jest dla ucznia istotne z punktu widzenia jego przyszłych działań.

4. Jak uczeń ma się dalej rozwijać?

W tej części nauczyciel stawia przed podopiecznymi wyzwania, zachęca ich do bardziej intensywnej pracy, stara się wpływać na rozwój ich mocnych stron. Tu jest miejsce na "podniesienie poprzeczki". Ta część informacji zwrotnej bywa bardzo osobista. Od niej może zależeć, czy uczeń nabierze chęci do podjęcia większego wysiłku i do rozwoju. Warto zaproponować mu więcej niż jedno wskazanie, zachęcić do wyboru lub poszukania możliwości.

Ten etap można także wykorzystać w pracy z „uczniem podwójnie wyjątkowym". To swoiste wyzwanie dla nauczyciela wspomagającego i nauczyciela przedmiotu, którzy w duecie ustalają wsparcie dla podopiecznego ze specjalnymi potrzebami edukacyjnymi.

Rzetelna, pełna, wyczerpująca informacja zwrotna jest szczególnie ważna przy pierwszym sprawdzaniu tego, jak uczniowie opanowali np. umiejętność poprawnego pisania (zaproszenia, opisu, charakterystyki), rozwiązywania zadań tekstowych, wykonania prezentacji, rysowania bryły przestrzennej czy skoku przez kozła. Daje wyjątkową okazję do uczenia się na własnych błędach, jest również wzorem dokonywania oceny koleżeńskiej i uczy argumentowania.

Informacja zwrotna przekazywana indywidualnie może znacznie ułatwić budowanie prawidłowych relacji między uczniem ze specjalnymi potrzebami edukacyjnymi a nauczycielami.

\section{Strategia IV: Umożliwianie uczniom korzystania z siebie nawzajem jako zasobów edukacyjnych (Sterna 2014)}

Strategia IV zakłada, że dzieci lepiej się uczą, jeśli korzystają z wiedzy i umiejętności swoich koleżanek i kolegów. Dla osób ze specjalnymi 
potrzebami edukacyjnymi ta metoda jest szczególnie ważna, zarówno w obszarze edukacji, jak i rozwoju społecznego (często bardzo nieharmonijnego, dysfunkcyjnego).

Opiera się ona na założeniu, że społeczny aspekt uczenia się jest bardzo ważny - dlatego proces edukacyjny jest tak organizowany, by uczniowie często mogli pracować w parach lub w większych grupach. Koordynowanie pracy zespołów wymaga kolejnych umiejętności i dobrego rozpoznania indywidualnych potrzeb uczniów. To w ramach tej strategii rozwija się kompetencje kluczowe (skuteczne komunikowanie się, praca w zespołach zadaniowych, realizacja prezentacji, aktywne słuchanie), a także uczy dokonywania oceny koleżeńskiej. Dzięki niej uczniowie mogą w bezpiecznym otoczeniu rozwijać swoje kompetencje społeczne, uczyć się współdziałania. To doświadczenie, które - bez wątpienia - przyda im się w dalszym, dorosłym życiu.

\section{Strategia V: Wspomaganie uczniów, by stali się odpowiedzialnymi autorami procesu swojego uczenia się (Sterna 2014)}

Wprowadzenie tej strategii przysparza nauczycielom najwięcej trudności. Wiąże się ona nierozerwalnie z wiarą ucznia w jego możliwości oraz z jego zainteresowaniem działaniami z zakresu świadomego uczenia się. Uczniowie zdolni lub „podwójnie wyjątkowi” łatwiej podejmują to ryzyko, co wynika bezpośrednio z ich wysokiego poczucia własnej wartości i ze świadomości własnych mocnych stron.

Zastosowanie strategii $\mathrm{V}$ dla innych uczniów ze specjalnymi potrzebami edukacyjnymi jest możliwe, wymaga jednak ostrożnego wprowadzania i uświadomienia sobie, że wcześniej omawiane strategie również wspierają odpowiedzialność i samosterowność uczniów. Świadomi nauczyciele motywują uczniów do dokonywania wyborów, najczęściej w zakresie pracy domowej (np. jedna lub dwie w semestrze, które należy przygotować) lub ilości materiału (np. selekcja spośród wielu przykładów reakcji chemicznych czy działań arytmetycznych). $\mathrm{Na}$ tym etapie zachęca się też uczniów do dochodzenia do własnych rozwiązań i sposobów ich prezentacji.

Strategii V sprzyja prowadzenie przez uczniów „OK-zeszytu”, zawierającego samodzielne notatki, zapisy, rysunki, skojarzenia, symbole, pomagające im uczyć się i rozwijać. Inną techniką związaną z planowaniem własnego rozwoju jest portfolio uczniowskie, umożliwiają- 
ce drobiazgowe planowanie działań, konsekwentną realizację planu, poprawną samoocenę i weryfikowanie postawionych celów. Stosując tę technikę, uczeń może sięgać wstecz i świadomie planować swoją naukę i przyszłość. Strategię V można podsumować słowami: „Uczniowie, którzy sami dążą do zdobywania wiedzy, mają większą motywację, więcej się uczą i lepiej rozwijają umiejętności metapoznawcze niż uczniowie, którzy jedynie wypełniają polecenia nauczycieli. A co nie mniej ważne - na pewno są w stanie powiedzieć, czego się nauczyli" (Moss, Brookhart 2014).

Wszystkie strategie oceniania kształtującego mają funkcję wspierającą nauczanie i uczenie się grupy ze specjalnymi potrzebami edukacyjnymi. Usprawniają procesy edukacyjne i rozwój umiejętności społecznych, uczą samooceny i brania odpowiedzialności za własny rozwój. Wszystkie działania z nimi związane muszą uwzględniać indywidualne potrzeby i wymagania, ale też w naturalny sposób poszerzać możliwości wszystkich uczniów, w tym tych ze specjalnymi potrzebami edukacyjnymi. 